\title{
ANTROPOMORFISME DALAM TEOLOGI ISLAM
}

\author{
Anthropomorphism in Islamic Theology \\ Ramli Awang \\ Fakulti Tamadun Islam \\ Universiti Teknologi Malaysia \\ Johor Bahru 81310, Johor, Malaysia \\ No Tel: +607-5535052 E-mel:ramly@utm.my \\ Roslan Abdul-Rahim \\ Pusat Bahasa dan Pengajian Asasi \\ Universiti Sultan Azlan Shah \\ Kuala Kangsar 33000, Perak, Malaysia \\ No Tel: +6019-7534512 E-mel:roshar@usas.edu.my
}

\begin{abstract}
Abstrak
Al-Qur'an yang diwahyukan kepada Nabi Muhammad s.a.w. mengandungi pengajaran akidah yang amat jelas. Pengisytiharan terhadap keesaan Allah dan tidak ada sekutu bagi-Nya disebut secara jelas dalam al-Qur'an (112: 1-4). Walau bagaimanapun metode memahami akidah ini telah bertukar corak dengan kehadiran golongan Ahli Hadis (Sunah) yang meriwayatkan hadis-hadis Nabi s.a.w. Kedapatan hadis-hadis tertentu yang memberikan personifikasi kepada sifat-sifat Tuhan seperti memiliki tangan, kaki, muka, dan seumpamanya. Kajian deskriptif bersifat kepustakaan ini menggunakan metod perbandingan. Beberapa tokoh Ahli Sunah seperti Abu al-Hasan al-Asy'ari, Ibn Khuzaymah, alDaruqutni, Abu Dawud, al-Tirmidhi, dan alSuyuti adalah antara contoh yang dikaji dalam artikel ini. Hasil penelitian mendapati sikap ketidak-telitian dalam memahami bahasa alQur'an dan kecenderungan ekstrim memberikan maksud literal terhadap ayat-ayat tentang sifat Allah antara punca merebaknya fahaman ini dalam kalangan tokoh tertentu dan mereka mewakili individu bukannya mazhab yang didukungi.
\end{abstract}

Kata Kunci: Akidah Islam; Ahli Hadis; Sifat Tuhan; Asy'ariyah

\section{Abstract}

The Qur'an that has been revealed through the Prophet Muhammad contains teachings on religious faith that are considered clear and explicit. This includes the declaration of the Oneness of God and His Unity as spelt out in Q.S. 122: 1-4. Nevertheless, the method for such faith understanding has since changed with the emergence of Muslim traditionists (Ahl alHadith) who have transmitted those traditions of the Prophet of Islam. There have been traditions that personified the attributes of God, such as, that God possesses hands, legs, face, etc. This work is a literary descriptive survey that utilizes the comparative method. A number of early Muslim figures like Abu al-Hasan alAsy'ari, Ibn Khuzaymah, al-Daruqutni, Abu Dawud, al-Tirmidhi, and al-Suyuti, are some examples of those surveyed in this article. The research outcome reveals the lack of care and meticulousness in understanding the language of the Qur'an, as well as extreme tendencies indulging in the literal understanding of Qur'anic verses concerning the attributes of God are some of the reasons for the spread of such theological position among certain theologians and that they turned out to be simply representatives of themselves and not representatives of the schools of thoughts that they might be part of. 
Keyword: Islamic Faith; Ahl al-Hadith; Divine Attributes, Al-Asy'ariyah

\section{Pendahuluan}

Menyimpulkan pandangan Ibn Taimiyyah (1263-1328 M) dalam Majmu ' al-Fatawa, Ibn Hazm (994-1064 M) dalam al-Fisal fi al-Milal wa Ahwa'wa al-Nihal, dan Imam Ahmad bin Hanbal (780-855 M) seperti yang dinukil oleh al-Sabuni (w. 449 H) dalam Sharh al- 'Aqidah al-Salafiyyah, Sayyid Abdul Aziz al-Sili (1993: 29-30) menegaskan bahawa Ahli Sunah adalah Ahli Hadis dan tergolong dalamnya al-Salaf. Alasan yang diketengahkan bagi menamakan mereka sebagai Ahli Hadis adalah penghujahan yang diguna-pakai oleh mereka ini dalam persoalan teologi adalah bersandarkan kepada Hadis (Sunah) Rasul serta mendahulukan nas daripada akal fikiran ( $\left.r a^{\prime} y u\right)$, qiyas, dan aliran mazhab.

Pegangan di kalangan banyak Ahli Hadis (Sunah) terhadap masalah sifat-sifat Tuhan ternyata bersifat literal. Mereka tidak memberikan takwil atau tafsiran yang berbeza daripada lafaz asal istilah yang disebut dalam hadis-hadis tersebut. Apabila terjadinya hal sedemikian, muncul istilah musyabbihah sepertimana yang disebut dalam tradisi perbincangan Ilmu Kalam: iaitu, golongan yang mensifatkan Tuhan dengan sifat-sifat yang ada pada manusia. Selain istilah musyabbihah, fahaman seperti ini disebut juga sebagai mujassimah, iaitu fahaman yang menyamakan sifat-sifat Tuhan dengan sifat-sifat makhluk (Abdul Shukor Husin, Zakaria Setapa, Mudasir Rosder, Hassan Mat Leh, Fatimah Ali, Wan Mohd Saghir Abdullah, Haji Isa@ Man Ismail, Abdullah Fahim Hj. Abdul Rahman, Hazir Sudin, Engku Ibrahim Engku Ismail, Wan Abdul Hamid Wan The, Roslan Abd. Jelani, Abdul Hanim Musa, Ibrahim Mohd Nor, Istilah Usuluddin dan Falsafah Islam, 1991: 233). Hal ini lantaran mereka berpegang kepada zahir ayat dan Hadis serta memahaminya secara 'literal'. Nama lain yang sering dihubungkan dengan fahaman ini ialah Hasywiyah lantaran memahami ayat-ayat Allah secara zahir sahaja (Abdul Shukor Husin et.al, 1991: 91).
Di antara mereka yang boleh kita anggap sebagai bersikap literal dalam perkara seperti di atas ialah al-Imam Abu Hasan al-Asy'ari (260-324 H). Ketika menyentuh tentang sifat tangan dan genggamam Allah, Imam al-Asy'ari mengatakan:

Telah bersepakat (Ahli Sunah) bahawa sesungguhnya Allah 'Azzawajal mendengar dan melihat, dan bagi Allah SWT itu ada dua tangan yang sentiasa terbuka. Dan bahawa bumi seluruhnya dalam genggaman Allah pada hari kiamat sementara langit dilipat dengan tangan kanan-Nya, tanpa melakukan takwilan yang lebih-lebih, dua tangan Allah itu tidak boleh diertikan sebagai nikmat-Nya. Sesungguhnya telah menunjukkan yang demikian itu akan kemuliaan-Nya kepada Adam yang dijadikan dengan tangan-Nya dan menghinakan Iblis lantaran takbur untuk sujud kepada apa telah dimuliakan-Nya dengan firman-Nya dalam Surah Sad, 38: 75: "Apa yang menghalangmu daripada turut sujud kepada (Adam) yang Aku telah ciptakan dengan tangan-Ku (lima khalaqtu bi yadayya)?" (al-Asy 'ari, Usul Ahl al-Sunnah wa al-Jama'ah, ed., al-Julyand 1997: 69).

Bagi beliau, istilah tangan di sini adalah hakikat, bukan majaz. Ia tidak boleh diertikan sebagai nikmat-Nya dan tidak pula dengan kekuasaanNya. Dalam tulisannya, al-Ibanah, beliau menyelar mazhab yang tidak sealiran dengannya yang memahami istilah 'yad'(tangan) itu sebagai qudrat, kekuasaan dan juga nikmat (al-Ibanah, t.t: 52-55). Pandangan ini amat berbeza dengan pandangan para pendukung aliran beliau dalam kalangan muta' akhirin seperti al-Razi (m. 606 H), al-Ghazali (m. $505 \mathrm{H}$ ), 'Abd al-Qahir alBaghdadi (m. $429 \mathrm{H}$ ), serta Ibn al-A'rabi (m. $543 \mathrm{H} / 1148 \mathrm{M}$ ) yang masing-masing memberi ruang kepada takwil. Mereka ini ialah para pendukung aliran Asy'ariyah yang menyalahi guru utama mereka. 


\section{Al-Qur'an dan Ayat Mutasyabihat}

Pada umum, ayat al-Qur' an boleh dikategorikan kepada muhkamat dan mustabihat. Ayat yang muhkamat adalah ayat-ayat yang jelas nyata manakala ayat yang mustabihat bersifat 'samarsamar'. Dalam ertikata yang lain, sebutan lafaznya boleh diertikan dalam maksud yang berlainan seperti, tangan (yad) dan mata ('ayn).

Al-Qur'an ada menyebut perkataan al-yad (tangan) dalam beberapa ayat dan disandarkan kepada Allah. Terjemahan literal berikut diberikan untuk memudahkan kefahaman sebagai perbandingan. Firman Allah: 'Allah berfirman: "Hai lblis! Apa yang menghalangmu daripada turut sujud kepada (Adam) yang Aku telah ciptakan dengan tangan-Ku? (lima khalaqtu bi yadayya). Adakah engkau berlaku sombong takbur, ataupun engkau dari golongan yang tertinggi?"' (al-Qur'an, 38: 75). Firman-Nya lagi: 'Dan orang-orang Yahudi itu berkata: "Tangan Allah terbelenggu" (yadullahi maghlulah). Tangan merekalah yang terbelenggu dan mereka pula dilaknat dengan sebab apa yang mereka telah katakan itu. Bahkan kedua tangan Allah sentiasa terbuka (bal yadahu mabsutatani). Ia belanjakan (limpahkan) sebagaimana yang ia kehendaki (al-Qur'an, 5: 64).

\section{Makna Metafora dan Aktual}

Istilah yang mushtabihat dalam al-Qur'an apabila dirujuk kepada penggunaan bahasa Arab yang asal, akan terserlah beberapa makna, metafora dan aktual. Ibn Manzur (1232-1311M), dengan memetik pandangan Ibn al-A'rabi, memberi banyak makna kepada istilah yad (tangan). Antaranya, yad bermaksud nikmat, kuat, qudrat, milik, kaya, sultan (kekuasaan), taat, jamaah, makan, penyesalan, ketundukan, dan lain-lain (Ibn Manzur, Lisan al-Arab, t.t.: 6: 4953). Imam Fakhr al-Din al-Razi pula menyebut bahwa makna yad apabila dihubungkan dengan Allah perlu ditakwilkan bagi membersihkan sifat Allah daripada sebarang bentuk penyerupaan makhluk. Beliau memberikan tiga pengertian yad sehubungan dengan ini (Asas al-Taqdis, 1993: 141):
i.) al-Qudrah (kekuasaan)
ii.) al-Ni'mat (nikmat)
iii.) Silah al-kalam 'ala sabil al-ta'kid (hubungan percakapan atas dasar menguatkan)

Allah ta'ala sama sekali tidak menyerupai sebarang makhluk dari aspek apa jua pun. AlQur'an menegaskan: “Tiada sesuatupun yang sebanding dengan (dhat-Nya, sifat-sifat-Nya, dan pentadbiran-Nya) dan Dia-lah yang Maha Mendengar, lagi Maha Melihat," (al-Qur'an, 42: 11). Allah ta'ala juga menyebut tentang mata ('ayn) yang ada pada diri-Nya. Berikut adalah ayat-ayat yang menyebut tentang hal ini:

iv.) al-Qur'an, 11: 37: “Dan buatlah bahtera dengan mata-mata (bi a'yunina) serta wahyu Kami; dan janganlah Engkau merayu kepada-Ku untuk menolong kaum yang zalim itu, kerana sesungguhnya mereka akan ditenggelamkan (dengan taufan)."

v.) al-Qur'an, 54: 14: "Yang belayar laju dengan mata-mata Kami (tajri bi a'yunina) sebagai balasan bagi orang-orang yang kufur ingkar!"

vi.) al-Qur'an, 20: 39: "Letakkanlah anakmu di dalam peti, kemudian lepaskanlah peti itu ke laut, maka biarlah laut itu membawanya terdampar ke pantai, supaya dipungut oleh musuh-Ku dan musuhnya; dan Aku telah tanamkan dari kemurahan-Ku perasaan kasih sayang orang terhadapmu; dan supaya engkau dijadikan atas mataKu ('ala 'ayni)." al-Qur'an, 52: 48: "Dan (dengan yang demikian) bersabarlah (wahai Muhammad) menerima hukum Tuhanmu (memberi tempoh kepada mereka), kerana sesungguhnya engkau dengan mata-mata Kami (bi a'yunina); dan bertasbihlah dengan memuji Tuhanmu semasa engkau bangun." 


\section{Fahaman Mujassimah Dalam Riwayat Hadis dan Tafsir}

Dalam kalangan Ahli Hadis kedapatan tokohtokoh yang berfaham mujassimah. Antaranya ialah Ibn Khuzaymah (223-311 H/838-924 M). Setelah mengemukakan ayat-ayat di atas, dia berkata:

"Maka wajib atas setiap mukmin mensabitkan bagi Penciptanya dan Tuhannya apa yang telah disabitkan oleh Allah berkenaan diriNya darihal mempunyai mata, dan selain mukmin pula ialah mereka yang menafikan dari Allah tabaraka wa ta 'ala apa yang telah disabitkan Allah dalam ketetapan al-Qur'an serta penjelasan Nabi," (Ibn Khuzaymah, Kitab al-Tawhid, 1994: 1:97).

Selanjutnya, beliau menyifatkan, "Sesiapa yang tidak mempercayai bahawa Allah telah mewahyukan dalam Kitab-Nya dan apa yang Ia nyatakan tentang Diri-Nya, maka orang itu bukan seorang Muslim.” Mempertegaskan lagi hal ini, beliau berhujah dengan ayat al-Qur'an, 16: 44: "Dan Kami turunkan kepadamu alQur'an agar kamu menerangkan kepada umat manusia apa yang telah diturunkan kepada mereka dan supaya mereka memikirkan."

Setelah itu dihujahkan pula dengan penegasan daripada Nabi s.a.w. yang menjelaskan bahawa Allah mempunyai sepasang mata! Penjelasan Nabi s.a.w. itu menurut beliau selaras dengan teks al-Qur'an. Iaitu al-Qur'an yang tertulis di antara dua kulit kitab, dan dibaca di masjidmasjid dan di pusat-pusat pengajian (Ibn Khuzaymah, 1994, 1: 97).

Bagi memperkukuhkan lagi alasan dakwaan di atas Ibn Khuzaymah membawakan hadis riwayat Abu Hurairah (m. 59 H/678 M) ketika membaca ayat Qur'an: "Sesungguhnya Allah menyuruh kamu supaya menyerahkan segala jenis amanah kepada ahlinya (yang berhak menerimanya), dan apabila kamu menjalankan hukum di antara manusia, (Allah menyuruh) kamu menghukum dengan adil. Sesungguhnya
Allah dengan (suruhan-Nya) itu memberi pengajaran yang sebaik-baiknya kepada kamu. Sesungguhnya Allah sentiasa Mendengar, lagi sentiasa Melihat," (al-Qur'an, 4: 58).

Di sini Abu Hurairah telah menunjukkan isyarat dengan jarinya kepada telinganya dan matanya bagi menunjukkan Allah mendengar dan melihat. Kemudian Abu Hurairah berkata: "Demikianlah yang aku dengar Rasulullah s.a.w. membacanya dan meletakkan jarijarinya" - iaitu menunjukkan kepada mata dan telinganya (Ibn Khuzaymah, 1994, 1: 98).

Meyakinkan lagi dakwaan Allah mempunyai mata, Ibn Khuzaymah turut meriwayatkan hadis daripada Nafi', maula 'Abd Allah bin 'Umar, daripada 'Abd Allah bin 'Umar katanya: Nabi s.a.w. bersabda: "Ingatlah bahawa sesungguhnya Allah tidak buta, ingatlah bahawa sesungguhnya Dajjal itulah yang buta matanya yang kanan, seolah-olah buah anggur yang keset."

Keterangan yang dinyatakan di atas memperlihatkan bahawa Ibn Khuzaymah telah memahami perkataaan 'ayn secara literal untuk membuktikan hujahnya bahawa Allah SWT mempunyai mata. Bagi meyakinkan pemahaman demikian dicontohkan dengan hadis yang memerihalkan butanya mata Dajjal. Perbandingan ini tiada lain kecuali mengarahkan kepada satu kefahaman bersifat penyerupaan Tuhan dengan makhluk. Pada hakikatnya, perkataan 'ayn dan kata terbitannya mempunyai banyak makna menurut pemakaian bahasa Arab.

Al-Qur'an telah menggunakan perkataan tersebut dengan dua kaedah dan makna iaitu secara literal dan metafora. Pada 21 tempat, al-Qur'an menggunakan istilah 'ayn untuk menunjukkan mata air atau air sungai. Dengan kata lain, dalam al-Qur'an, perkataan 'ayn telah digunakan dalam dua bentuk, sama ada secara aktual atau metafora. Dalam contoh aktual atau makna sebenar al-Qur'an mencontohkan: 
al-Qur'an, 4: 43: “Maka hendaklah kamu bertayamum dengan tanah - debu, yang suci, iaitu sapukanlah ke muka kamu dan kedua tangan kamu (wa aydikum). Sesungguhnya Allah Maha Pemaaf, lagi Maha Pengampun."

al-Qur'an, 5: 28: “Demi sesungguhnya! Jika engkau hulurkan tanganmu (ilayya yadaka) kepadaku untuk membunuhku, Aku tidak sekalikali akan menghulurkan tanganku kepadamu untuk membunuhmu. Kerana sesungguhnya aku takut kepada Allah, Tuhan yang mentadbirkan sekalian alam."

al-Qur'an, 5: 38: “Dan orang lelaki yang mencuri dan orang perempuan yang mencuri maka (hukumnya) potonglah tangan mereka sebagai satu balasan dengan sebab apa yang mereka telah usahakan, (juga sebagai) suatu hukuman pencegah dari Allah. dan (ingatlah) Allah Maha Kuasa, lagi Maha Bijaksana.'

Istilah 'tangan' dalam bahasa Arab disebut sebagai 'yad'. Kata jamaknya 'ayd'. Makna perkataan 'aydiyakum' (tangan-tangan kamu), 'yaddaka' (tangan kamu) dan 'aydiyahuma' (tangan-tangan kedua mereka) dalam ayat-ayat di atas adalah tangan sebenar yang menjadi sebahagian anggota badan manusia. Ia tidak boleh difahami lain dari makna zahir tersebut.

Manakala dalam bentuk metafora, al-Qur'an memberi contoh 'mata' ('ayn). Firman-Nya:

al-Qur'an, 28: 9: “Dan (ketika melihat kanakkanak itu) berkatalah isteri Firaun: "(Semoga ia menjadi) cahaya mata bagiku dan bagimu; janganlah kamu membunuhnya; Mudahmudahan ia berguna kepada kita, atau kita jadikan Dia anak”. Padahal mereka tidak menyedari (kesudahannya)."

al-Qur'an, 19: 26: "Maka makanlah dan minumlah serta bertenanglah hati dari segala yang merunsingkan. Kemudian kalau engkau melihat seseorang manusia, maka katakanlah: Sesungguhnya aku bernazar diam membisu kerana (Allah) al-Rahmōn; (setelah aku menyatakan yang demikian) maka aku tidak akan berkata-kata kepada sesiapa pun dalam kalangan manusia pada hari ini."

Dengan ini terbukti bahawa istilah 'ayn dan 'aynan dalam ayat-ayat tersebut menggambarkan kegembiraan dan kepuasan hati (bukan difahami maknanya secara literal) sebagai 'ia biji mataku' atau 'sejukkan matamu'. Dalam istilah yang lain disebut sebagai 'penyejuk mata'.

Ibn Khuzaymah dalam tulisannya, Kitab alTawhid, menulis di bawah tajuk: "Kedudukan Pencipta kita Yang Maha Tinggi, dan di atas Kursi-Nya, di atas segala sesuatu," (1994, 1: 233). Bagi memperkukuhkan sabitan dakwaan di atas, dikemukakan pula nas-nas al-Qur'an berikut:

Iaitu (Allah) al-Rahman, yang bersemayam di atas 'Arasy, (al-Qur'an, 20: 5).

Sesungguhnya Tuhan kamu ialah Allah yang menciptakan langit dan bumi dalam enam masa lalu ia bersemayam di atas 'Arasy, (al-Qur'an, 7: 54).

Begitu juga dengan firman-Nya: Allah, Tuhan yang menciptakan langit dan bumi serta segala yang ada di antara keduanya dalam enam masa, kemudian ia bersemayam di atas 'Arasy, (alQur'an, 39: 4).

Dan firman-Nya: Dan Dialah yang menjadikan langit dan bumi dalam enam masa, sedang 'Arasy-Nya, berada di atas air, (al-Qur'an, 11: 7).

Menggambarkan keimanannya kepada zahir ayat tanpa takwil sedikit pun sebagai Ahli Hadis, Ibn Khuzaymah menegaskan:

"Kami beriman dengan perkhabaran AllahJalla wa 'Ala: Bahawa pencipta kita berada di atas 'Arasy-Nya, kami tidak merubah kalam Allah dan kami tidak mengatakan selain apa yang dikatakan kepada kami. Kami tidak mengatakan sepertimana yang diucapkan oleh 
golongan al-Mu'tallah al-Jahmiyyah yang mengatakan bahawa Dia istawla (memilik atau memerintah) di atas 'Arasy, bukannya Istiwa' (bersemayam), mereka merubah perkataan tersebut tidak sepertimana yang diperintahkan mereka untuk berkata sedemikian, sepertimana yang dilakukan oleh Yahudi ketika Allah memerintahkan mereka berkata: 'hittah', tetapi mereka berkata: 'hintah.' Kata-kata itu menyalahi perintah Allah - Jalla wa 'ala begitu juga dengan kalangan al-Jahmiyyah," (Kitab al-Tawhid, 1994, 1: 233).

Al-Daruqutni (m. 385 H/995 M) pula, seorang Ahli Hadis yang lain, dalam tulisannya (alSifat, t.t., 1: 34, hadis no. 33) membawakan hadis berikut bagi menggambarkan kursi yang dikaitkan dengan Allah:

"Sesungguhnya kursi-Nya seluas langit dan bumi, dan berkerik-kerik seperti berkeriknya pelana tunggangan baru apabila ditunggang lantaran beratnya beban".

Hadis lain yang hampir serupa diriwayatkan oleh ak-Bazzar seperti dinukil oleh al-Haythami, (Majma'al-Zawa'id, 1994,1:83):

Daripada 'Umar radiyallahu anhu bahawasanya seorang wanita datang bertemu nabi s.a.w dan mengemukakan satu permintaan: "Doakan aku supaya aku berada dalam kalangan orang-orang yang masuk syurga". Nabi s.a.w. kemudian memohon dengan nama Allah dan bersabda: "Kursi Allah sangat luas seperti langit dan bumi dan ia berkerik-kerik seperti pelana tunggangan baru apabila ditunggang lantaran beratnya".

Seperti benda-benda lain, Kursi berada di atas air. Dalam huraian selanjutnya, Abu Dawud (202-275H) seorang Ahli Hadis mazhab Sunni yang terkenal dalam tulisannya, (Sunan, t.th.,4: 231) meriwayatkan hadis di bawah:

Sabdanya: Tahukah kamu berapa jarak antara langit dan bumi. Mereka menjawab: Kami tidak mengetahuinya. Sabdanya: Sesungguhnya jarak di antara langit dan bumi adalah 71, 72 atau
73 tahun. Kemudian langit yang di atasnya dengan jarak yang demikian pula, sampai tujuh langit. Kemudian di atas langit ketujuh itu ada laut, jarak antara bawahnya dan atasnya seumpama antara jarak satu langit dengan satu langit yang lain, kemudian di atas itu delapan ekor kambing antara kukunya dengan lututnya seumpama jarak antara satu langit dengan langit yang lain, kemudian di atas belakang mereka al-'Arasy yang jarak antara bawah dengan atasnya seperti satu langit dengan langit yang lain, kemudian Allah tabaraka wa Ta 'ala berada di atas itu semua," (Ibn Khuzaymah, Kitab al-Tawhid, 1994,1: 234-235, no. 144; al-Tirmidhi, Sunan, 1983, 5: 96-97).

Maksud dengan lapan ekor kambing itu dijelaskan lagi oleh Muhammad Ibn Jarir alTabari (840-923 M) dalam Tafsirnya, Tafsir al-Tabari (t.t., 23: 583). Al-Suyuti (1445-1505 M) pula menambah selain daripada menyebut kepala mereka itu berada di 'Arasy pada langit ketujuh manakala kaki-kaki mereka mencecah di bumi terkebawah, mereka juga mempunyai tanduk sepertimana tanduk kambing yang jarak antara satunya dengan yang lain berukuran perjalanan selama 500 tahun (al-Durur alManthur, t.t., 10: 92).

Meskipun ada tafsiran yang berbagai, pengertian malaikat yang berupa dengan rupa kambing lebih sesuai dipadankan lantaran di sana ada sebutan kuku, lutut dan belakang.

Al-Tabari (Tafsir al-Tabari, t.t, 23: 583) menulis:

"Diceritakan daripada al-Husayn, katanya: Aku mendengar $\mathrm{Abu} \mathrm{Mu}^{\prime}$ 'adh berkata, telah menceritakan kepada kami 'Ubayd, katanya: Aku mendengar al-Dahhaq berkata sehubungan dengan firman Allah (dan 'Arasy Tuhanmu pada saat itu dipikul oleh lapan malaikat - Surah alHaqah, 69: 57). Telah berkata setengah mereka: Lapan baris, tidak diketahui bilangan mereka kecuali Allah. Berkata setengah yang lain lapan malaikat atas rupa kambing dan berkata yang lain bahkan yang dimaksudkan dengannya adalah lapan malaikat." 
Al-Tha'labi (m. 427H/1035 M) ada meriwayatkan bahawa sekumpulan Ahli Tafsir menyebut para malaikat itu berupa manusia, kaki mereka berada di bumi yang ke tujuh, manakala kepala dan bahu-bahu mereka di langit ke tujuh (al-Kasyf wa al-Bayan, 2002, 2: 233). Tafsiran malaikat itu juga dipersetujui oleh Ibn Abi Hatim yang meriwayatkan daripada $\mathrm{Sa}$ 'id bin Jubayr sebagai berkata: Lapan (malaikat) (Tafsir Ibn Abi Hatim, 1997: 3264).

Imam Jalal al-Din al-Suyuti dalam al-Durur al-Manthur (t.t., 10: 43) juga ada memetik satu riwayat daripada Wahab bin Munabbih (m. 114H/732 M) sebagai berkata:

"Ada empat malaikat yang memikul 'Arasy atas bahu-bahu mereka. Setiap seorang daripada mereka ada empat wajah: Iaitu lembu jantan, singa, helang dan manusia. Setiap satu daripada mereka ada empat sayap, dua sayap atas muka mereka (melindungi) agar tidak melihat kepada 'Arasy yang menyebabkannya pengsan, sementara dua sayap lagi berfungsi untuk terbang. Pada lafaz yang lain: Ia terbang dengan keduanya, kaki-kaki mereka di tanah manakala Arasy pula di atas bahu-bahu mereka. Tiada bagi mereka itu percakapan kecuali menyebut; Maha Suci Allah yang Maha Kuat, memenuhi keagungan-Nya langit dan bumi."

Riwayat Ka'ab al-Ahbar (m. 32H/652 M) pula menyebut:

"Allah menjadikan tujuh langit dan bumi dan jarak di antara langit-langit itu adalah sama dengan jarak antara bumi dan langit dan menjadikannya berat. Kemudian Dia mengangkat "Arasy-Nya di atas kedua-duanya dan bersemayam diri-Nya di atasnya. Maka setiap langit berkerit-kerit disebabkan berat Allah Yang Maha Berkuasa, seperti pelana unta yang baru berkerit-kerit apabila ada penunggang menunggang buat pertama kalinya."

Barangkali inilah sumber asal riwayat yang menyangkut antropomorfisme. Ia adalah daripada Ka'ab al-Ahbar, yang asalnya seorang rabbi Yahudi dan memasukkan cerita tidak masuk akal seperti ini ke dalam hadis-hadis dan dinisbahkan kepada nabi s.a.w. Hadis-hadis ini dipetik oleh Ahli Hadis dan Tafsir tanpa saringan yang berhati-hati.

Dalam tafsirnya, Tafsir Muqatil (t.t., 1: 157), Muqatil bin Sulayman (m. 150H/767 M) membahaskan ayat Qur'an, "Kursi-Nya luas meliputi langit dan bumi...." (al-Qur'an, 2: 255), beliau menyebut:

Kursi dipikul oleh empat malaikat. Setiap satunya ada empat wajah, kaki-kaki mereka di bawah padang pasir yang bertempat di bumi paling bawah, perjalanan 500 tahun, jarak antara setiap bumi perjalanan 500 tahun; malaikat yang wajahnya berupa manusia, dan dia adalah penghulu rupa, dia berdoa untuk rezeki bagi anak-anak Adam; dan malaikat yang wajahnya atas rupa penghulu binatang ternak memohon rezeki bagi binatang ternak, dialah lembu jantan. Sentiasalah malaikat yang berupa lembu jantan itu atas wajahnya seperti orang yang tunduk semenjak disembah anak lembu selain dari al-Rahman 'Azzawajal, dan malaikat yang wajahnya atas rupa penghulu burung, dia memohon rezeki bagi burung-burung, ia adalah helang dan malaikat yang berupa penghulu binatang buas dan dia memohon rezeki bagi binatang liar, ia adalah singa."

\section{Kesimpulan}

Berdasarkan keterangan-keterangan yang dinyatakan sebelum ini, ada kalangan ulama Hadis (Sunah) yang berfahaman musyabbihah atau mujassimah. Mereka ini terkesan daripada pegangan terhadap hadis-hadis yang diriwayatkan secara riwayat (hadith alriwayah) tanpa membuat penganalisisan dan kritikan terhadap matan hadith. Memahami ayat-ayat mutasyabihat berkaitan sifat Allah tidak boleh difahami secara literal atau aktual kerana akan mensabitkan penyerupaan Allah dengan makhluk dan fahaman seperti ini mengundang berlakunya khurafat dalam akidah 
Islam. Pegangan kepercayaan seperti ini boleh membawa penyimpangan daripada akidah Islam yang sebenar berlandaskan al-Qur'an dan sumber-sumber hadis yang sahih. Meskipun kedapatan fahaman seperti ini dalam aliran mazhab Ahli Sunah Waljamaah, pandangan tersebut mewakili individu dan tidak mewakili mazhab. Individu yang berfahaman seperti itu ditolak pandangannya dan fahaman menyimpang seperti itu tidak boleh dinisbahkan sebagai mewakili mazhab Ahli Sunah Waljamaah.

\section{Rujukan}

Abu al-Hasan al-Asy'ari. (t.t.). Al-Ibanah 'an Usul al-Diyanah. Tahkik 'Abd Allah Mahmud Muhammad 'Umar. Beirut: Dar al-Kutub al'Ilmiyyah.

Abu Ishaq Ahmad al-Tha'labi. 2002. Al-Kasyf wa al-Bayan. 10 jilid. Tahkik Abi Muhammad bin Asyur. Beirut: Dar Ihya' al-Turath al-Arabi.

Al-Azdi, Abu Dawud Sulayman ibn al-Asy'ath al-Sijistani. (t.t.). Sunan Abi Dawud. 4 jilid. Beirut: Dar al-Fikr.

Al-Balkhi, Abu al-Hassan Muqatil ibn Sulaiman. (t.t.) Tafsir Muqatil. (Maktabah al-Syamilah).

Al-Daruqutni, Abu al-Hasan Ali bin Umar. 2009. Kitab al-Sifat. Riyad: Dar al-Sumay'i lil Nasyr wa-al-Tawzi'.

Al-Imam Abi al-Hasan al-Asy`ari. 1997. Usul Ahl al-Sunnah wa al-Jama'ah. Tahkik Muhammad al-Sayyid al-Julyand. Azhar: alMaktabah al-Azhariyah li al-Turath.

Al-Razi, Fakhr al-Din. 1993. Asas al-Taqdis. Tahkik Ahmad Hijazi al-Saqa. Beirut: Dar al-Jil.

Al-Suyuti, Abu Bakr Jalaluddin. (t.t.). Al-Durr al-Manthur. (Maktabah al-Syamilah).

Al-Tabari, Muhammad ibn Jarir. (t.t.). Tafsir al-Tabari. (Maltabah al-Syamilah).
Al-Tirmidhi, Abu 'Isa bin Surat. 1983. Sunan al-Tirmidhi, 5 jilid. Beirut: Dar al-Fikr.

Ibn Abi Hatim, Abdulrahman bin Muhammad bin Idris al-Razi. 1997. Tafsir Al-Qur'an alAzim. Tahkik As'ad Muhammad al-Tayyib. Riyad: Makatabah Nazar al-Baz.

Ibn Khuzaymah, Abu Bakr Muhammad bin Ishaq. 1994. Kitab al-Tawhid wa Ithbat Sifat al-Rabb 'Azzawajal. 2 jilid. Tahkik 'Abd al'Aziz bin Ibrahim. Riyad: Maktabah al-Rusyd.

Ibn Manzur, Jamaluddin Muhammad bin Mukarram. (t.t.). Lisan al-'Arab, 6 jilid. Tahkik Abdullah Ali al-Kabir (et.al.). Iskandariyah: Dar al-Sha'b. 